\title{
"Suburbs are not so bad I think": Stevie Smith's Problem of Place in 1930s and '40s London
}

\author{
Kristin Bluemel
}

"London and its outskirts became Greater London in the inter-war period" (Bowdler 103). With this simple declaration, geographer Roger Bowdler identifies the physical transformation of English landscape that underlies my analysis of Stevie Smith's literary fantasies about the suburbs. Described at the time as the "outskirts" and "fringes" of the capital, London's suburbs achieved their regional identity as intermediate or in-between spaces-between town and country, commerce and agriculture, bricks and birds, crowds and calm. Semi-detached houses, arterial roads, new underground stations, building societies, mortgages, vanishing woods, disappearing hedgerows, consumed villages, diverted streams-all of these geographical signs of tremendous social change accompanied the post-World War I mandate to build "Homes fit for Heroes."

Suburbs had existed as identifiable regions in landscape and the public imaginary long before the 1919 Housing or Addison Act led to the first interwar development boom. Yet never had suburbs so troubled people's ideas of what it meant to be a Londoner or to be English. Smith merits special consideration in studies of this suburban trouble because, in contrast to the vast majority of $1930 \mathrm{~s}$ and ' $40 \mathrm{~s}$ writers, she does not naively celebrate or thoughtlessly excoriate the suburb in her writings. Instead, she uses her position as suburban insider to describe and analyze more acutely than others the ambivalent role of the suburb in English life. To

Kristin Bluemel is Associate Professor of English at Monmouth University. She is editor of the journal The Space Between: Literature and Culture, 1914-1945 and author of On the Borders of Modernism: Dorothy Richardson's Pilgrimage (Georgia, 1997) and George Orwell and the Radical Eccentrics: Intermodernism in Literary London, which is forthcoming from Palgrave. 
explore the relations between suburban geographical fact and Smith's suburban literary fantasies and to show the importance of these relations for the study of twentieth-century English culture, I attempt to do three things in this essay. First, I provide a geographical framework based on study of the architectural, social, and economic landscape of the London suburbs, focusing particularly on the transformation of the village and countryside, two regions traditionally regarded as the base of English national feeling. Second, I show how popular period texts in the two subgenres of the ramble book and the series novel represent a nostalgic effort to reclaim the lost world of pre-suburban England at the very moment the suburb was perceived as England's most dynamic, developing region. Third, I analyze the implications of these suburban spaces - real and imaginary-for literary scholarship, which is biased toward texts written by intellectuals who tend to demonize the suburbs and their inhabitants.'

As John Carey argues, most intellectuals of the early to mid-twentieth century found the suburb so distressing they came in their writings to equate suburban geography with a degraded humanity, treating both with venomous contempt. Many fantasized, in private if not public forums, that the suburbs and their inhabitants would disappear. ${ }^{2}$ Writing from the margins of London and its literary circles, Stevie Smith provides us with texts that challenge in delightful and instructive ways the disturbing literary norm that Carey presents. ${ }^{3}$ I conclude this essay with an analysis of Smith's affectionate representations of her lifelong home, the suburb Palmers Green, focusing on materials that distinguish her from the most famous "highbrow" writers of her time in order to complicate our understanding of the generating sites of twentieth-century English literature. ${ }^{4}$ While Smith is not immune from the widespread tendency Carey describes of conflating suburban homes with the people living inside them, in her three novels, selected short stories, poems, and in the sketches "Syler's Green" and "A London Suburb," the suburb becomes an extraordinarily suggestive, dynamic site for discovering the conflicted meanings of Englishness during the 1930s and '40s. My analysis of Smith's writings emphasizes the political and ideological implications of her suburban constructions, focusing especially on their gendered resistance to and reproduction of middle-class, or more particularly lower-middle-class, suburban ideals. ${ }^{5}$

The story of the English interwar suburb starts during World War I, when the Ministry of Munitions became the first arm of the central government to involve itself in suburban residential building. Following the example of the London County Council, the Ministry formed estates that were designed for workers in munitions and aeroplane factories (Bowdler 103). Such direct involvement on the part of the central government in suburban development was unusual. After the war, the government's involvement was represented by the 1919 Housing or Addison Act, which came out of Lloyd George's Homes Fit for Heroes movement. In Bowdler's words, the Addison Act "encouraged the building of suburban housing and thereby enshrined - for the first time in official housing policy - the desirability of the suburb" (105). The London County Council estates, some of the largest estates in Europe, were the most dramatic instance of new housing created from this Act. The LCC oversaw the development of the huge Bellingham, Downham, and 
Beacontree estates, the latter eventually housing some 120,000 people (Bowdler 108). Government policy makers and developers regarded such scale as necessary for cost reduction and as a response to the ever-expanding population of the capital. And that expansion was astonishing. John Stevenson records that "the south east of England absorbed almost two-thirds of the total population increase of the whole country during the inter-war years and the London conurbation increased from $71 \frac{1}{2}$ million people in 1921 to $81 / 2$ million by 1939 " (95). Stevenson sees in the mushrooming suburbs of London and in the new industrial estates of the mid-1930s signs of England's recovery from the Depression and support for his argument that the ' 30 s deserve to be remembered as much for the affluence they brought to a majority of the population as for the unemployment and hunger marches they brought to the distressed areas (92).

Emphasizing the astonishing growth of the period that gave birth to the Beacontree estates or the acres of semi-detached houses on the fringes of London, Bowdler and Stevenson imply that the terrible housing needs of Londoners, and especially working-class Londoners, were met through good policy and enlightened development - that the heroes did for the most part find homes. A very different perspective emerges from Deirdre Beddoe's feminist study Back to Home and Duty. Rather than focusing on the completed suburban houses, her history emphasizes the social impact of incomplete or inadequate housing development. She too mentions that 1920 s housing was seen as a reward for masculine military service, but she also notes that "housing was a women's issue," and a fraught women's issue at that (90). According to Beddoe, "[i]n 1918 the housing shortage stood at 600,000 , five times its pre-war level" (90). Yet even such an appalling statistic about housing needs was not enough to inspire response by middle-class policy makers. It took rent strikes by urban women to focus the middle-class public's eye on the shortage of moderately priced, adequately comfortable housing (Beddoe 90).

The housing problems of families and city planners brought tremendous opportunities for builders, estate agents, and building societies, all of whom were delighted that a significant percentage of the London renting population was turning itself into suburban homeowners. George Orwell, perhaps the most famous of England's rebel writers, expresses an entirely conventional horror upon witnessing this transformation. In The Clergyman's Daughter, displaced villager and amnesiac heroine Dorothy Hare is saved from destitution by a distant cousin who finds her a job as a suburban schoolmistress. Dorothy goes to work for the awful Mrs. Creevy of Ringwood House Academy for Girls on Brough Road in Southbridge. Orwell describes Southbridge as "a repellent suburb ten or a dozen miles from London" (214). He continues viciously: "Brough Road lay somewhere at the heart of it, amid labyrinths of meanly decent streets, all so indistinguishably alike, with their ranks of semi-detached houses, their privet and laurel hedges and plots of ailing shrubs at the cross-roads, that you could lose yourself there almost as easily as in a Brazilian forest" (214). In other words, Southbridge is Orwell's heart of darkness.

By 1939, when Coming Up for Air appeared in the bookstands, Orwell still chose to represent the London suburb as a kind of hell on earth, the worst lie 
Western civilization had to offer its own natives. The first fifteen pages of the novel are a gleeful excoriation of the widely-publicized amenities of the suburb. Orwell's hero, George or "Fatty" Bowling, comments:

\begin{abstract}
When you've time to look about you, and when you happen to be in the right mood, it's a thing that makes you laugh inside to walk down these streets in the inner-outer suburbs and to think of the lives that go on there. Because, after all, what is a road like Ellesmere Road [that is, his road]? Just a prison with the cells all in a row. A line of semi-detached torture-chambers where the poor little five-toten-pound-a-weekers quake and shiver, every one of them with the boss twisting his tail and the wife riding him like the nightmare and the kids sucking his blood like leeches. (12)
\end{abstract}

The crux of the problem for both Georges - Bowling and Orwell-is political. ${ }^{6}$ The poor five-to-ten-pound-a-weekers think they own their houses and "have what's called 'a stake in the country"' (15). The insidious effect of this conviction is that the lower-middle-class inhabitants of Bowling's suburb are turned into the "devoted slaves" (15) of the Cheerful Credit Building Society, Sir Hubert Crum, its baronet chieftain, and the capitalist ideology that legitimizes the predatory actions of both. In other words, by 1939 Orwell and his fictional spokesman do not just repeat Orwell's earlier criticism in The Clergyman's Daughter about the soul-stifling effects of the suburb's endlessly repeating structures, but are critical of the political effects such physical conformity represents. As Bowling notes, any one of the "poor downtrodden bastards sweating his guts out to pay twice the proper price for a brick doll's house ... would die on the field of battle to save his country from Bolshevism" (15).

Although Coming Up for Air is certainly unusual in its suggestion that suburban development was part of a governmental policy to suppress Bolshevism, many people in the years between the wars complained about the suburbs' tendency to "sprawl" - to eat up the English countryside and replace it with "haphazard and restless ugliness" (Jackson 113). ${ }^{7}$ For a nation that had turned to images or fantasies about its countryside and villages to identify and understand itself, it is easy to understand how English people outside of London, or even those inside the city, center saw the gobbling up of grass and woodlands as an assault upon their heritage and national identity. George Orwell is again representative of feelings popular among cultural elites. In Keep the Aspidistra Flying, Gordon Comstock finds temporarily relief from the strains of his ongoing war on money by rambling in the countryside twenty miles outside London. Orwell's fictional woods fall before the novel's promised suburban pleasures. The novel's ironic ending replaces country scenes with nothing other than Gordon's vision of redemption in a suburban life defined by marriage, babies, a villa, a radio, an aspidistra, and a place in the "straphanging army" (238).

Geographical facts suggest the material origins of Orwell's and other writers' suburban fears and fictions. During the interwar years, Londoners had to reconcile themselves to advertised suburban satisfactions instead of bucolic renewal since development was making an irreversible claim on the traditionally rural English 
countryside. In the sixty years between 1870 and 1930 the acreage of grassy lands in Middlesex fell by half, the numbers of cattle by $3 / 4$. Acre upon acre of agricultural land was developed; by the outbreak of the Second World War, hundreds of thousands of new houses covered countryside that had once defined and separated detached, autonomous villages like Hornchurch, Ruislip, and Morden as recently as the end of the previous war (Bowdler 114). Like Gordon Comstock, suburbanites learned to exchange the benefits of proximity to villages and woods seen as "authentically English" for the benefits of having an expanded, modern public transportation system linking them to the city's center. By the mid-1930s, 2.5 million people were traveling every day within greater London. In part as a consequence of such movement, "the commuter [came to challenge] the Cockney for the title of the Typical Londoner" (Bowdler 114).

Michael T. Saler's study of the London Underground in interwar London tells an engrossing story about the growth of the subway system under the direction of Frank Pick, the autocratic executive on the London Passenger Transport Board. Pick's passion and vision made possible the real and imagined ascendancy of the commuter in interwar London. Pick wanted to wed the social ideals of the nineteenth-century arts and crafts movement to modern art and postwar transportation technology in order to create a new community or corporate identity for London. He believed that the underground tracks would give the above ground metropolis a coherent shape, transforming what he and many critics saw as a sprawling, incoherent city into a bounded whole. Modern art was to provide the means by which Pick hoped to achieve this ideal. He commissioned artists like Charles Holden to fashion a unified style for the Underground, from the design of its waste bins to the architecture of its stations (27-28).

Pick's determination to achieve a whole or wholesome London is a prominent example of the kind of trouble the suburbs posed to the Londoner's imagination. Where was London amid the sprawl? How could it be recognized? Even named? Pick and Orwell, in their very different ways, represent "highbrow" approaches to the problems of regional identity posed by the suburb. In what follows, I look at two "lowbrow" forms of writing, ramble books and series novels, to show how a mirror image of the troubled suburban fantasies of elites can be found in popular literature.

In ramble books and series novels, nostalgia for the lost countryside and village motivates the plots, settings, and, one assumes, readership. Such attractive nostalgia for lost geographical and social forms emerges out of the suburban destruction of greenery that those forms implicitly lament. Paradoxically, such books would have found a part of their audience in the Gordon Comstocks of London, the members of the strap-hanging army who only found the daily journey bearable through the distraction of novels, even novels that omitted or even regretted their very existence (Bowdler 111)!

The ramble book is exemplified by titles like The Fringe of London; Being Some Ventures and Adventures in Topography or Where London Sleeps: Historical Journeying into the Suburbs. ${ }^{8}$ All of these ramble books boast an avuncular first-person narrator who is bent on discovering the old (the authentic) within the 
new suburban terrain. We need look no farther than the forced pseudo-eighteenthcentury prose style of the extended subtitle of The Fringe of London-"on rambling round the outskirts of London, and of the unexpected turns, trials, and triumphs that lie in the path of the wayfarer"- - to discover the depth of yearning for the past that undergirds these books. The genteel, tedious nostalgia of the following passage from Where London Sleeps is also exemplary: "Londoners live and sleep in places that in one's lifetime had been remote and inaccessible. The City, London's magnetic pole, attracts to itself for the working day a vast army of blackcoated toilers numbering hundreds of thousands, who pour out again at dark, homewards ..." (Bell vii). The author's comparison of suburbanites to the undead of Dante's hell or Eliot's Waste Land exposes the way suburbs challenged Londoners' regional identity. On the one hand, suburbanites are dark, damned outsiders who do not know London history and thus are not true Londoners. On the other hand, such outsiders can be taught to see London's "authentic" pre-suburban history and thus to recognize their true responsibilities and be reborn and redeemed as Londoners.

A more entertaining example of such instructive confusion over regional identity is evident in Thomas Burke's The Outer Circle: Rambles in Remote London. This ramble book distinguishes itself by mocking the ineptitude and ignorance of the urban narrator-rambler as much as that of the suburban subjects under review. In other words, its classical pastoral dynamic is more expertly diverting than that of the other ramble books, although it too reveals the ambiguous status of the suburb in the Londoner's imagination. Burke's narrator, a Londoner, begins by admitting a "shameful incident": he got lost in London during Armistice Week. This unthinkable catastrophe happened as he was trying to escape by bus from the chaos of visiting revelers. When the bus deposits all riders in the dark of Sherrick Green, he is aghast to learn from a shopkeeper that he is not in Middlesex or Hertfordshire but his own native town:

Ten minutes to Willesden. I was in London, then-at Sherrick Green, N.W. I stood on the deserted pavement and burned with shame. Sherrick Green, London; and I had never heard of it! A corner of my own city, where men ate and slept, and loved and hated; where tradesmen built bonny businesses; where babies were born; where children went to school and grew into men and women; and I knew not of it. Other remote suburbs I knew and loved. I had seen the lilac bushes exterminated from Crofton Park. I was about when the tramway was extended from Tooting to Hampton Court. I had watched the steady surge of houses from Lewisham to Sidcup ... . Yet Sherrick Green I had cut. (11-12)

Trivial as it may seem, this writing is doing the interesting cultural work of transforming suburbanites into Londoners. Burke is correcting his, and presumably his suburban readers', impression that Sherrick Green is outside an urban space and identity. He emphasizes that he "was in London," in "my own city." While Burke is not trying to transform suburbanites into Bolsheviks, his narrative is built out of and supports the same suburban fantasies as Orwell's more "highbrow" fiction. For both Orwell and Burke, redemption is located in the grand cycles of loving and 
begetting that transpire behind identical suburban doors. Of course, the narratives assume their readers can appreciate the absurdity of their mock-heroic visions and are able to chuckle gently, or in Orwell's case bitterly, at the notion of building a regional identity out of prams, radios, and commuter trains.

Books like The Outer Circle, which try to minimize the claims of the suburbs on Londoners' regional identities, had to compete with unapologetic celebrations of suburbs in publicity pamphlets like The Story of Golders Green and Its Remarkable Development. Published by Messrs. Ernest Owers, Ltd., Auction and Estate Offices, The Story of Golders Green is not written to translate suburban into urban history, but to show without irony "the remarkable growth of the district in very recent years" (n.p.). ${ }^{9}$ Packed with fold-out maps, tables on general district rates and poor rates and graphs of birth and death rates, population growth, and commuter statistics, its only humorous contents are its advertisements. All the earnest endeavors of local champions are still felt, years later, in the proud announcement that "J. Richards Ltd., The Dairy Specialists" has branches throughout Golders Green, Hampstead, and Hendon. More telling is the proclamation in big capital letters in the center of the ad that this is LONDON'S SAFEST MILK. This bold cry distills all the fascinating contradictions of the suburban space: the assertion of purity, of a superiority implicitly derived from a historic connection to freely romping cows (London's SAFEST milk), and the underdog yearning to be seen as part of, while competing with, the larger entity, London, that defines and determines the fate of J. Richards, Ltd., and Golders Green more generally.

This slender book concludes with a chapter titled "Why Golders Green Succeeded," listing the things about which suburbs have always boasted: convenient access via public transportation to the city center, on the one hand, and open spaces for easy development and access to "natural beauties" on the other. Ironically, the author measures the success of Golders Green through the drastic reduction of the community's unenclosed greens to the wee triangle of common ground in front of the tube station (34). A black and white photograph accompanies the description of this much-reduced green, and it is telling that the "green" memorialized in the suburb's name, cannot be distinguished from the gray of the Underground's paving stones. ${ }^{10}$

Readers who find materials for cynicism and regret rather than rejoicing in The Story of Golders Green and Its Remarkable Development would be likely to enjoy the light, humorous series fictions of P. G. Wodehouse, Angela Thirkell, E. F. Benson, or even Dorothy Sayers, all of which evoke in novel after novel or story after story a world far removed from interwar suburban alienation or promotion. These writers would have depended on an urban audience, among them, let's imagine, a fair number of suburban commuters, for a substantial percentage of their book sales. Yet none were brave enough to place their typically upper-class heroes or heroines in a recognizably suburban environment. Benson's Lucia is in the villages of Riseholme and Tilling when she is not in fashionable London; Thirkell's characters contend with the trials of gentle life in the County of Barsetshire (whose maps suggest a striking affinity between Thirkell's territory and Milne's Hundred Acre Wood); Wodehouse's Bertie Wooster drags us along on his aimless, humorous 
wanderings about town; and Sayer's Lord Peter Whimsy and Harriet Vane solve their mysteries in the countryside, historic university towns, or London proper. Like the purchasers of the "Stockbroker Tudor" or "By-Pass Variegated" villas that Osbert Lancaster lampoons in Pillar to Post (62-63, 68-69), the characters in these series fictions offer the English imagination modernity dressed up in the nostalgic forms associated with traditional English life, what Priestley called the "First" or old England (300).

Of course intellectuals of the interwar years denounced the "false art and pretentious vulgarity of the Tudor fake" and resisted the nostalgic appeals of popular fictional forms (Bowdler 121). Scholars are more likely to know and remember the suburban satires by these same intellectuals, such as the novels by Huxley, Orwell, Wells, and Lawrence that Carey catalogs. Certainly Evelyn Waugh's Vile Bodies deserves mention for containing the passage of suburban satire scholars are most likely to cite:

\begin{abstract}
Nina looked down and saw inclined at an odd angle a horizon of straggling red suburb; arterial roads dotted with little cars; factories, some of them working, others empty and decaying; a disused canal; some distant hills sown with bungalows; wireless masts and overhead power cables; men and women were indiscernible except as tiny spots; they were marrying and shopping and making money and having children. The scene lurched and tilted as the aeroplane struck a current of air.
\end{abstract}

"I think I'm going to be sick," said Nina. (284)

Carey calls this passage, which appears when Nina and Ginger are leaving on their honeymoon, "Waugh's verdict on suburban England" (48). ${ }^{1} \mathrm{He}$ assumes that right-minded readers will immediately recognize the need to condemn Nina/Waugh as horrifyingly elitist. Carey doesn't bother to note, as most critics usually and dutifully do, the ambiguous origin of Nina's nausea (is it the vision of the suburbs or the tilt of the plane?). Nor does he consider how to weigh Nina's revulsion from the suburb against Waugh's satire of her and the other vacuous Bright Young Things, a satire that is far more devastating than his satire of the suburbs.

Carey vividly, if not quite fairly, treats the most familiar and famous early twentieth-century authors the same way he treats Waugh, selecting a nasty anti-suburban comment out of the context of his or her lived politics or larger literary production. He wants to illustrate how elites of all political stripes despised the suburban masses and, in their literary fantasies, created a terrain which is consistent with Hitler's Mein Kampf..$^{12}$ Simon Dentith, guided by a similar interest in "high" culture's relation to the suburb, examines representations of the suburbs in poetry of the ' $30 \mathrm{~s}$. He establishes a less depressing version of Carey's intermodern suburban debate, or what he on second thought calls "the various kinds of name-calling" that emerged around the "icons of a new degeneracy," like arterial roads, filling stations, cinemas, the wireless, and semi-detached bungalows (108-109). Analyzing the generic difficulties exposed by poems like MacNeice's "Birmingham" and sections of "Autumn Journal," he turns to Smith's "Suburb," citing twenty-seven lines beginning with the following: 
Round about the streets I slink

Suburbs are not so bad I think

When their inhabitants can not be seen,

Even Palmers Green. (Collected Poems 81-82)

This poem prompts Dentith to ask an important ethical-political question about the relation between poetic speaker and suburban subject: "Does it make a difference here that the point of view of this poem is that of a pedestrian inhabitant of the suburb in question (albeit one who slinks about at night), rather than [MacNeice's] motoring correspondent?" (120). His answer? "Well, it doesn't and it does." It "doesn't," in Dentith's view, because Smith employs the problematic "characteristic generic dispositions" of the period-_"the reading off of inauthentic lives from inauthentic architecture and the trivial paraphernalia of petty-bourgeois lives" (120). Dentith is also troubled by Smith's "pervasive comic irony at the suburbs' expense," which may keep her from "treat[ing] the lives of the inhabitants of the suburbs with appropriate seriousness" (119). On the other hand, he realizes that Smith does not replicate in her poetry the kind of snootiness he finds in suburban poems by Betjeman, Auden, Day Lewis, and MacNeice. Attempting to define Smith's difference, attempting in other words to place her, Dentith concludes rather opaquely:

The witty and self-mocking misanthropy is aware of no other social perspective [presumably, no other social perspective outside of the suburb] by which to measure the inhabitants of Palmer's Green, so that the ironies of the poem are selfconsuming ones. Stevie Smith, in other words, transforms the thematics of thirties suburban poetry in ways that push the poem toward self-destruction or tonal illegibility. (120)

Oddly enough, this judgment is presented as the reason Smith "does" make a difference; it seems to be the positive evidence we're asked to take into consideration before responding to the dilemma of difference that Dentith outlines.

I find little comfort in the notion that Smith's poem and speaker self-destruct and little value in Dentith's verdict of "tonal illegibility." The latter term seems a confusing way of saying, "I can't place this poem" or "This poem doesn't fit into the places I have opened up for it." To see and hear the difference "Suburb" makes for our understanding of ' 30 s writing, we have to accept that the poem, like Smith, simply doesn't fit. Smith, her speaker, even her rhymes and rhythms, are out of place, located somewhere in between known spaces and categories. Although Dentith dislikes the superior, superficial position of MacNeice's motoring correspondent, at least it helps him figure out how to place the poem, how to read it, and how to judge it. Among other things, the "pervasive comic irony" of "Suburb" upsets our confidence in our poetic "placing" skills. In particular, it troubles our assumptions about the "appropriate" poetic tone of "seriousness," challenging our aesthetic and ideological judgments. Readers who value Smith's "low" comic forms and effects (e.g., the silly rhyme "think" and "slink"), will find that "Suburb"'s humor produces opportunities for social connection just as much as its irony repro- 
duces relations of social distance. In contrast to Dentith, I argue in what follows that Smith's suburban identifications, no matter how stressed by feelings of disdain or fear, lead us toward a valuable, "different" vision of the suburb in " $30 \mathrm{~s}$ poetry and toward a more sophisticated understanding of the problem of place in London (and especially literary London) during the ' 30 s and '40s.

The geography of the suburbs shaped Smith's life. It is no surprise that her literary executor, James MacGibbon, begins his preface to Smith's Collected Poems by discussing domestic details of her home in Palmers Green, noting that "[Stevie] ran the small house, a place of fascinatingly ugly décor, not a stick of which, as far as could be observed, had ever been changed since [her] arrival [at age four]" (8). Smith commuted for years from Palmers Green into London to work as a personal secretary to baronet publishers Sir Neville Person and Sir Frank Newnes. Her job brought her literary friends and associates, but her suburban home and alliances always kept her on the margins of the cosmopolitan literary culture she sought to enter. ${ }^{13}$ Not exactly a suburban housewife nor yet urban intellectual, Smith struggled to orient herself in relation to multiple and seemingly incompatible identities and places. Publication of Novel on Yellow Paper in 1936 helped her find a way out of her exhausting emotional, geographical bind; it allowed Smith to exchange her culturally undervalued status of commuting clerk for the culturally valued status of author and novelist without forcing her to change her domestic loyalties or habits.

By the mid-1930s, Florence Margaret Smith had become Stevie Smith. Biographers James Barbera and William McBrien surmise that Smith's transformation meant that "in the manner of most writers she began to lead a double life. 'Peggy" she remained to a segment of her old Palmers Green world, but another self called 'Stevie' was ascendant" (41). It is easy to understand why Smith wanted to keep the ascendant writer-self a secret from the world of Palmers Green; her fiction and poetry often satirized the suburbs and suburbanites Peggy Smith seemed to admire. It is more difficult to understand her decision to stay in Palmers Green year after year, risking exposure and rejection. Smith's increasingly down-at-heels suburb must have been very important to her emotionally and socially, offering a kind of comfort, protection, and sustenance she could not find elsewhere. ${ }^{14}$ The importance of this suburb to Smith's art is evident from its repeated appearance, in mildly disguised forms, in her poetry, fiction, and short prose of the ' $30 \mathrm{~s}$ and ' $40 \mathrm{~s}$.

Smith's 1937 poem "The Suburban Classes" is a funny, ironic verse about convincing the suburban classes to commit mass suicide. Its first four lines, spoken in the voice of a self-satisfied official or simply self-satisfied snob, are:

There is far too much of the suburban classes

Spiritually not geographically speaking. They are asses.

Menacing the greatness of our beloved England, they lie

Propagating their kind in an eightroomed stye. (Collected Poems 26)

Voicing an absurd extreme of the anti-suburban logic that was so common in "highbrow" publications, Smith's poem links elimination of suburbanites to the formation of a healthier nation. The mythical suburban vices of unquestioning obedience to authority, quest for fashion, and voracious appetites for print and con- 
sumer goods will all be used against them to create a sounder English body. The key is manipulating their nationalist emotions, convincing them that "Your King and your Country need you Dead" (Collected Poems 26). The poem's humor keeps readers from totally identifying Smith's attitude towards her subject with the contempt of its speaker, although the poem's satire also distances Smith from the inhabitants of Palmers Green. ${ }^{15}$

More sophisticated in its suburban satire is Novel on Yellow Paper, the book whose brilliant, quirky humor first made Smith famous. Like Orwell's George Bowling, Smith's suburban protagonist, Pompey Casmilus, gleefully exposes the absurd trick or swindle of the suburban promise. But unlike Bowling, Pompey locates the swindle in the materials of suburban women's lives. From her position in "Bottle Green," she considers the evil effects of advice columnists who persuade unmarried women they will only find happiness in marriage, home, and children. In other words, Smith exposes the ideological contradictions hidden within fantasies that could transform blushing suburban brides into Orwell's Mrs. Bowling, riding her husband like the nightmare. Her hilarious satire of young married women's attempts to live the fairy-tale told by estates developers and women's magazines of a special bliss awaiting them in domesticity recalls the jaundiced view of family life conveyed by the fourth line of "The Suburban Classes": "Propagating their kind in an eightroomed stye." The contempt in both texts can be read as a sign of Smith's sense of superiority to those women Pompey calls "silly fatheads" or conversely, as an attempt to defend herself against their social success, their ability to embody in motherhood and suburban homemaking the loftiest cultural ideal held out for women.

Smith's fiction demonstrates that she remained sensitive to this cultural pressure and aware of the conflicts it could inspire in the lives of unmarried women years after Pompey "lost" the suburban marriage game in Novel on Yellow Paper. For example, Celia of the post-war novel The Holiday tells us that she loves her Aunt and her family life, "but I like also to go out and see how the other people get along, and especially I like to see how the married ladies get along" (27). These married ladies are not like the urban intellectuals Smith befriended-women who worked, like her, in publishing houses and strove to win income and fame from their writing. Rather, they are Celia's suburban neighbors. Flattered at first by Celia's wondering praises about the amount of attention they direct towards their husbands - "How can you keep it up, Maria?"- they become defensive in the face of her persistent, perverse questioning about the marriage experience:

[T]hey begin to wish not to stress how martyr-like wonderful it is, and they begin to say how much one is missing if one does not have it; so I have had trouble with my married women friends .... But I can see that they have to do it if they are going to have a darling husband and a darling home of their own and darling children, they have to do it, there is no other way, and if you do not then you will live lonely and grow up to old solitude. Amen. $(28)^{16}$

Celia, like Smith and Smith's other fictional alter egos, is not condemned to loneliness and isolation. She shares a home with Auntie Lion or the Lion of Hull, who is 
tenderly described as "strong, happy, simple, shrewd, staunch, loving, upright and bossy" (28). She is Smith's unlikely hero for an unheroic, postwar age. Aunt appears in all of Smith's novels, and she comes to stand for a new ideal of Englishness rooted in the habits and characteristics of the nation's lower-middle-class suburb dwellers.

Smith's heroines' bravado in the face of various threats, the threat of marriage with its demands on the one hand and the threat of "old solitude" on the other, resonates with Smith's reflections on her own youthful attitude towards marriage. She told her friend Kay Dick that she did nearly marry because "[a]t that period I thought it was the right thing to do, one ought to - that it was the right thing to do, one ought to - that it was the natural thing to do, hey ho- but I wasn't very keen on it" (72). ${ }^{17}$ Her repetition of the phrase "it was the right thing to do, one ought to," her implication that marriage once represented for her a duty every good English woman would fulfill, conveys her sense of the terrible weight of the social codes that separated conventional from unconventional feminine behavior. In the same interview she confesses not contempt but admiration for women who have children: "Why I admire children so much is that I think all the time, 'Thank heaven they aren't mine"" (73). This facetious comment expands upon a sentiment that Smith shared with Naomi Mitchison upon learning that Naomi had lost a baby. Noting that "[ $\mathrm{t}]$ his child bearing puts a woman at almost as great a disadvantage as advantage," she expresses admiration for women who become mothers because the bravery demanded of them in the service of their progeny is of a kind "no timid selfish person could willingly give" (274).

Barbera and McBrien read Smith's 1939 short story "The Herriots" as her attempt to imagine her way in and out of suburban life with a husband and child (Me Again 2). The heroine of this story is named Peg and, like Peggy Smith, she is raised by an aunt and great aunt who bring her up to think that "men were to fetch and to carry" (75). Her disillusionment comes when she discovers that her mother-in-law, Mrs. Herriot, "unquestioningly put the wishes of the men first .... She felt that she had married into an Indian or Turkish family" (75). Mrs. Herriot's complaint to Peg's husband, Coke Herriot, about his wife leads him to strike Peg. This violence, and the quarrels and tears that precede it, are the family's secret as they struggle with Coke's joblessness, Peg's depression, the baby's cries, and Mrs. Herriot's intrusions. Relief from the trials hidden within the suburban flats in the big houses of the pre-War period, in which "nobody could get away from anybody, there were always nerve storms and people crying themselves to sleep," comes in the form of a rich eccentric old woman who pays Peg to be her companion (76). When Coke's father retires and Coke assumes his position as traveling plumber, the suburb that has nurtured the nerve storms becomes the haven Peg and Coke always wanted it to be. The suburb, finally, is not exposed as a site of a special kind of hypocrisy, of false promises and secret family strife, but as a place that can offer a distinct kind of safety though it may nurture as well the characteristic stresses of interwar English life. We can choose to read in Peg's words to her beloved old lady some of the emotional costs Smith paid for choosing to remain with Aunt in Palmers Green: "'If only we could get away,' said Peg, 'life would be so different. But I love Bottle 
Green so much, too; sometimes I think I could not go away, but always I say this: If we could get away. It is the sort of thing one says, nothing really"' (79-80).

After the war, Smith praised many of the qualities of suburban life that she exposed to ridicule in her interwar and wartime writings. In 1947 she wrote for the BBC's Third Programme an essay called "Syler's Green," which is a fond recollection of suburban life designed for a nation of listeners grappling with the task of building out of the rubble of the Blitz a viable regional ideal and national identity. In Smith's essay, the suburb is not an upstart community, responsible for destroying countryside and English traditional life, but rather a solid, comforting artifact of English history. While admitting that her suburb has "gone down" in a social sense, "the people are as bustling and happy as ever, and one thing they seem to me to have in quite extraordinary abundance, and that is babies" (Me Again 96). In this comic but tender piece, the flourishing babies are not the source of despair, but one of the things upon which suburban residents are to be "envied and congratulated" (96). The other is their "rich community life" that prevents them from "existing in a bored box-like existence that is what people think of suburb life" (97).

This beloved suburb is what Smith called in her 1949 essay "A London Suburb" a "true suburb, an outer suburb" (Me Again 103). In this later sketch, the suburb functions in ways that the country or city center function in the interwar ramble books or series novels that I've discussed; it is a sign of authentic, traditional English life, the basis for a robust regional identity, the source for writers of inspiration and for readers of a comforting nostalgia. Smith, the satirist, sounds like a publicity pamphlet in the following paragraph:

The virtue of the suburb lies in this ... it is wide open to the sky, it is linked to the city, it is linked to the country, the wind blows fresh, it is a cheap place for families to live in and have children and gardens .... And behind the fishnet curtains in the windows of the houses is the family life-father's chair, uproar, dogs, babies and radio. (104)

It is notable that all the things that Smith lists in this last sentence as indicative of suburban virtue - "father's chair, uproar, dogs, babies and radio"-were missing from her Palmers Green home. We can see Smith acting in "A London Suburb" the way Aunt acts in The Holiday, making pronouncements for others that contradict her own social practices. Celia catches Aunt in such a maneuver at the breakfast table when Aunt is telling stories of her own childhood, her sad, widowed father, and his wise wife who "was a good wife to him, she was what a woman should be" (37). But as Celia tells us:

[T]here was something of the Begum in her eagle managing eye and in the pronouncement "- what a woman should be." $\mathrm{Ha}$, ha, I thought to myself, but there was no He-Begum in your life, no there was not, Alec Ormstrode loved you, but you would have none of him, no, you were not for him "what a woman should be." No, you are the Begum Female Spider who has devoured her suitors and who lives on and makes these crocodile-like pronouncements, and who is like a lion with a spanking tail who will have no nonsense. (38) 
Celia's reflections upon her Aunt isolate and celebrate the quality of principled nonconformity, or what I call "radical eccentricity," that is vital for critics to recognize if we're to gain a more nuanced understanding of and better appreciation for literature and culture of the " $30 \mathrm{~s}$ and " $40 \mathrm{~s} .{ }^{18}$ Described as an "eccentric" by critics of her period and increasingly admired as such by those of our own, Smith deserves to be recognized as heroically "radical" in her departure from the cultural norms for women and in her departure from the literary norms of the "high" modernists given credit for creating the best writing of the early twentieth century. ${ }^{19}$ Recognizing she was not "what a woman should be," Smith drew strength from her position on the fringes of fashionable London literary circles to create a self and literary voice out of the materials and emotions of the suburbs so despised by her intellectual peers. ${ }^{20}$ It is the aim of this essay to show how the literary forms and ideological meanings posed by Smith's suburban writings challenge existing critical constructs of twentieth-century literature that privilege an urban modernism at the expense of what could be called suburban intermodernism. These writings are able to achieve significant effect precisely because they question so intensely the stability of Smith's eccentric position, identity, and artistry in the process of satirizing dominant beliefs of mainstream and elite English culture.

\section{Notes}

${ }^{1}$ I am indebted to John Carey's extensive documentation of early and mid-twentiethcentury anti-suburban sentiment (46-70). Recalling in some ways Andreas Huyssen's argument in "Mass Culture as Woman: Modernism's Other" (44-62), Carey's larger argument is that modernist writing was designed to turn newly educated (or "semi-educated") readers created by late nineteenth-century educational reforms into the metaphor of "the mass" in order to defeat their power, remove their literacy, deny their humanity, and so preserve the intellectual's privilege (21). Those intellectuals who Carey attacks include the usual suspects of Nietzsche, Hamsun, Hardy, Lawrence, Yeats, Eliot, Lewis, Waugh, Huxley, Greene, and Conrad, and the not-so-usual suspects of Shaw, Wells, Gissing, Priestley, Woolf, and Forster. Conan Doyle and, to a certain extent, James Joyce are among the astonishingly few writers who emerge from Carey's study with their reputations intact.

${ }^{2}$ Having cited hilariously incriminating passages from a wide array of books (both "high-" and "lowbrow") in order to show the pervasive, anti-suburban horror evident in intellectuals' writings, Carey adds:

Like "masses," the wor[d] "suburban" is a sign for the unknowable. But "suburban" is distinctive in combining topographical with intellectual disdain. It relates human worth to habitat. This history of the word shows how a development in human geography that caused widespread dismay came to dictate the intellectuals' reading of twentieth-century culture. (53)

For a refreshing break from such intellectual dismay, see Richards, who defends the suburb as "our own contemporary vernacular" (19), worthy of serious analysis due to the puzzle it poses about society; how could something known for deficient taste represent an ideal home for ninety out of one hundred Englishmen (17)?

${ }^{3}$ Carey identifies Smith and John Betjeman as two writers who, "intent on finding an eccentric voice could do so by colonizing this abandoned [suburban] territory" (66). Al- 
though the ominous imperialist metaphor that shapes this statement about Smith might lead one to suspect Carey will trounce her too, in fact he treats her poetry with sympathy, recognizing that "her taste for suburban sensations is keen and immediate" (67). Having identified a tendency among intellectuals to treat the suburb as a site of a specifically female triviality, Carey draws a parallel between suburban experience and the features that distinguish Smith's poetic voice. Seeming to anticipate Alison Light's feminist argument, he notes that Smith "evolved a model of female writing that avoids and undercuts the kinds of dignity and authority that males have appropriated" (69). However, Carey then invites Light's criticism by placing Smith outside literary history, calling her "uncategorizable," and throwing into question her connections to other intellectuals by claiming her poems "achieve cultural significance because they are entirely careless of cultural significance" (69).

${ }^{4}$ Frances Spalding, one of Smith's most sensitive and sympathetic readers, struggles to position Smith in English literary culture. She settles for this odd description: "[Her] work was and is difficult to pigeon-hole. Her play with a small range of ideas, often repeated, introduces a philosophical element that makes her a kind of lower highbrow, halfway between a solid middlebrow such as Rosamond Lehmann and the sparkling philosophy of Iris Murdoch" (224). Other critics have tried more or less successfully to ally Smith with modernism or postmodernism. Certainly either of the modernist or postmodernist classifications, suggestive as they are of some kind of historical connection between Smith, other English writers, and English literary history, are preferable to the decision by the Norton Anthology of English Literature editors to describe Smith as "one of the absolute originals of English literature, whose work fits into no category and shows none of the characteristic influences of the age" (Abrams, et al. 2221).

${ }^{5}$ As many have noted, Smith's politics are hard to pin down. Her refusal to ally her artistic practice with either Tory or Labour or Catholic ideologies during these most political of decades has certainly contributed to her marginal position within standard accounts of ' $30 \mathrm{~s}$ or " $40 \mathrm{~s}$ literature. So have her generic practices. She was publishing prose in the ' $30 \mathrm{~s}$ when poetry and drama were the fashionable forms for elite writers, and she was trying to publish poetry in the " 40 s when everyone else was publishing their war novels and memoirs. She is missing from Hynes's The Auden Generation, and even Valentine Cunningham's monumental, revisionary British Writers of the Thirties does not treat her work in any depth. It took the feminist critical studies of the ' 90 s to really bring Smith into literary critical discussion. See, for example, Severin; Dowson; Montefiore; Lassner; Plain; Schneider.

${ }^{6}$ In contrast to Orwell and his heroes, Smith and her heroines do not look to politics for solutions to social and cultural problems. In The Holiday (written during the war and published in 1949), Smith's alter ego Celia explicitly rejects the solution of anti-middle-class politics recommended by the "intelligent revolutionary," Basil, a figure based on her friend George Orwell (104). See 105-108 for a defense of the suburb populated by "the less wealthy sort of middle-class person" (105).

${ }^{7}$ Alan Jackson describes the late Victorian "fertile ground" that paved the way for the development of semi-detached London in the early decades of the twentieth century. He starts with the middle-class suburbs, like Ealing and Sidcup, where "woods and fields were never very far away, and urbs mixed most harmoniously with rus" (21). Next, he treats the lower-middle-class suburbs, like Bowes Park, Wood Green, and Smith's Palmers Green, where houses were smaller and closer together but more like properties in Ealing than in the inner-city. Finally, he describes the poorer railway suburbs, like Edmonton and southern parts of Woods Green, where artisans, clerks, and the middle strata of the urban working class lived in houses that stood "rank behind rank like soldiers at a military review" (22).

${ }^{8}$ The only one of these ramble books readers would be likely to recognize today is J. B. Priestley's English Journey, which carries the astonishing subtitle Being a Rambling but 
Truthful Account of What One Man Saw and Heard and Felt and Thought during a Journey through England during the Autumn of the Year 1933. Priestley famously described the outer suburb as the site that came closest to representing the "Third" or modern England (300). See also Fox-Davies; Fearon; Pathfinder.

${ }^{9}$ See Jackson 74-89 for a case study of Golders Green. He describes Ernest Owers as "an almost legendary figure in the world of estate agents," a man who started out as a solicitor's clerk and grew to be one of the most successful developers during the Golders Green bonanza (74).

${ }^{10}$ For an innocent contribution to the dialectic of development and nostalgia nurtured by the literature of the suburbs, see Clive Smith's Golders Green As It Was, which consists of reproduced photographs from the years of Golders Green's most ferocious and, in some minds, tragic development.

${ }^{11}$ Carey reads Waugh's verdict on suburbia as a reaction to the consumption of his childhood home on the edge of Hampstead Heath by - what else?- Golders Green (48).

${ }^{12}$ See Carey 198-208. In his postscript, Carey notes how the population explosion of the last half of the twentieth century has inspired academic predictions of massive numbers of human deaths with conclusions that "agree broadly with Hitler's warning in Mein Kampf" (213). Carey reminds readers that "we are just as responsible for [the frightening figures of population explosion] as anyone else" and suggests that our own impulse to see the problem elsewhere should "make us sympathize more with the intellectuals' predicament [in the early twentieth-century], however repellent we may find the cultural attitudes they favoured and the remedies they proposed" (213). It is worth noting that outside of this sentence, Carey himself does not extend or encourage sympathy for the intellectuals' fear of the masses. Waugh, Woolf, Lewis, and Wells all end up looking like monsters.

${ }^{13}$ Biographers Jack Barbera and William McBrien cite the "mandarin approval" Smith's first novel earned from literary heavy weights Noel Coward, Raymond Mortimer, and John Hayward, and they record her invitation from Hayward to lunch with Eddy Sackville-West, Rosamond Lehmann, and Joe Ackerley. Yet many of Smith's best friends came from the now little-known ranks of London-area women writers and editors, including Sally Chilver, Olivia Manning, Inez Holden, Helen Fowler, Cecily Mackworth, Alice "Liz" Ritchie, Narcisse Crowe-Wood, and members of what Barbera and McBrien call the "Hampstead set" that met in the home of Betty Miller (156).

${ }^{14}$ In 1956 Smith could write to an editor: "Very few in this suburb know me as Stevie Smith \& I should like it to stay that way" (Me Again 301). She had been in Palmers Green for fifty years at this point.

${ }^{15}$ See Dentith for a reading of this poem that is less confident about Smith's distance from the speaking voice. He suggests that Smith's ironies are, as in "Suburb," self-consuming ones that "suggest no outside perspective on the topic of the poem, unless it be the complexities of the performance itself" (121).

${ }^{16}$ One of Mamaine Koestler's letters to her twin sister, Celia Goodman, written upon learning of the engagement of Sonia Brownell to George Orwell, sheds anecdotal historical light on The Holiday's words about spinsterhood. In contrast to those friends of Orwell's who saw Brownell as a gold digger and regarded the marriage as a farce, Mamaine thought news of the alliance "splendid." She continues, "I am most impressed by Sonia's courage in making what must have been a very difficult decision. It will of course be wonderful for George, and may save him; in any case I think it can only be good for Sonia to be released from the crushing difficulties of life as a single woman, of finance, or dreary work and solitude" (111). One wonders upon reading this what really takes more courage: accepting an offer of marriage from a wealthy, dying man or turning down an offer of marriage to continue "difficulties of life as a single woman"? It may be of interest to note that when Celia 
Goodman received this letter, she had already turned down an offer of marriage from Orwell.

${ }^{17}$ Barbera and McBrien tentatively propose that Smith is referring in these comments to her relationship with Frederick "Eric" Hyde Armitage, the neighbor in Palmers Green immortalized as the hapless Freddy in Novel on Yellow Paper, Over the Frontier, and the poem "Freddy" (58-62). Spalding is more confident that Smith became engaged to and then disengaged from Armitage and that Pompey's romantic misadventures with Freddy, embarked upon in the contexts and according to the strictures of their shared suburban community, are based on Smith's. She notes:

By her late twenties and early thirties Stevie had reached a critical age from the point of view of marriage, on which the suburbs placed much emphasis. She would have been exposed to this pressure which occasional invitations underlined. "Would you maybe be thinking of a walk at all?" reads one postcard she received from an $\mathrm{H}$. G. Hilton who lived at New Barnet. (94-95)

${ }^{18}$ I want to distinguish my notion of radical eccentricity from any simple, unmotivated or purposeless display of unconventionality. Smith shared with Irish playwright Denis Johnson her impatience with those who took up unconventional behaviors in the name of unconventionality. Her satire of Kay Boyle, whom she anticipated visiting in 1938 with her friend Nina Condron, is quite funny in this regard: "[I]t's all very odd, weird somehow, I mean Kay ... seems to spend her whole time Being Unconventional, this sort of thing, Why put cups on the table, why not on the floor, the English are so conventional, if you want to throw somebody out of the window, why not do it, the English are so conventional ...." (Me Again 268).

${ }^{19}$ Affirming Smith's radical eccentricity as an artistic strength presents a dilemma for those who want to move her closer to the center of critical discussion about twentiethcentury culture. On the one hand, we want to emphasize her originality and criticize the aesthetic norms that have, for so long, kept her out of "serious" literary history. On the other hand, once we make the bid for Smith's inclusion in that serious literary history, recognized as modernism by most scholars, we're stuck defending that history in the process of trying to reform it. In the words of Astradur Eysteinsson, "the notion of modernism is dependent upon the intrigues of canonization," among other things (131): "[I]n analyzing the concept of modernism, we are constrained to deal with works that have been at the center of modernist studies, if only in order to combat the notion that the concept is restricted to a 'natural' reading and interpretation of these works" (151).

${ }^{20}$ My valorization of Smith as suburban eccentric, representing a distinctive interwar literature based on the qualities of ordinary (i.e., lower-middle-class) Englishness, should be read alongside of Rita Felski's exploration of relations between identity, shame, and the lower middle class. Finding the petite bourgeoisie "peculiarly resistant to the romance of marginality," Felski suggests provocatively that "there are genuine, perhaps irresolvable antagonisms between the cultural values of the intelligentsia and those of the traditional lower middle class" (44). My portrayal of Smith as an intellectual who shows us the possibility of a fruitful, though not untroubled, relationship between her lower-middle-class structures of feeling and her status as a writer does not necessarily contradict Felski's conclusions but rather shows how important it is for scholars to listen to Smith's unusual, discomforting voice.

\section{Works Cited}

Abrams, M. H., et al. The Norton Anthology of English Literature. New York: Norton, 1993. 
Barbera, Jack, and William McBrien. Stevie: A Biography of Stevie Smith. London: Papermac, 1986.

Beddoe, Deirdre. Back to Home and Duty. Boston: Pandora, 1989.

Bell, Walter George. Where London Sleeps: Historical Journeying into the Suburbs. London: John Lane, 1926.

Bowdler, Roger. "Between the Wars: 1914-1940." London Suburbs. Ed. Andrew Saint. London: Merrell Holberton with English Heritage, 1999. 103-129.

Burke, Thomas. The Outer Circle: Rambles in Remote London. London: George Allen and Unwin, 1921.

Carey, John. The Intellectuals and the Masses: Pride and Prejudice among the Literary Intelligentsia, 1880-1939. New York: St. Martin's, 1992.

Cunningham, Valentine. British Writers of the Thirties. New York: Oxford University Press, 1988.

Dentith, Simon. "Thirties Poetry and the Landscape of Suburbia." Rewriting the Thirties: Modernism and After. Ed. Keith Williams and Steven Matthews. New York: Longman, 1997. 108-123.

Dick, Kay. Ivy and Stevie: Ivy Compton-Burnett and Stevie Smith, Conversations and Reflections. 1971. New York: Allison and Busby, 1983.

Dowson, Jane. Women, Modernism, and British Poetry 1910-1939: Resisting Femininity. Burlington, VT: Ashgate, 2002.

-. Women's Poetry of the 1930s: A Critical Anthology. New York: Routledge, 1996.

Eysteinsson, Astradur. The Concept of Modernism. Ithaca, NY: Cornell University Press, 1990.

Fearon, Henry Bridges. Tramping around London: Forty-One Walks in London's Country. London: Country Life, 1933.

Felski, Rita. "Nothing to Declare: Identity, Shame, and the Lower Middle Class." PMLA 115 (2000): 33-45.

Fox-Davies, Moyra. Eighty Miles around London. London: T. Nelson, T.C. and E.C. Jack, 1934.

Hawkins, F[rancis]. The Story of Golders Green and Its Remarkable Development. Golders Green: Messrs. Ernest Owers, Ltd., Auction and Estate Offices, 1923.

Huyssen, Andreas. After the Great Divide: Modernism, Mass Culture, Postmodernism. Bloomington, IN: Indiana University Press, 1986.

Hynes, Samuel. The Auden Generation: Literature and Politics in England in the 1930s. Princeton, NJ: Princeton University Press, 1972.

Jackson, Alan A. Semi-Detached London: Suburban Development, Life, and Transport, 1900-1939. London: George Allen and Unwin, 1973.

Koestler, Mamaine. Living with Koestler: Mamaine Koestler's Letters, 1945-51. Ed. Celia Goodman. New York: St. Martin's, 1985.

Lancaster, Osbert. Pillar to Post: The Pocket Lamp of Architecture. New York: Transatlantic Arts, 1938.

Lassner, Phyllis. British Women Writers of World War II: Battlegrounds of Their Own. New York: St. Martin's, 1998.

Light, Allison. "Outside History? Stevie Smith, Women Poets and the National Voice." English 43 (1994): 237-259.

MacGibbon, James. Preface. Smith, Collected Poems 7-12.

Maxwell, Gordon S. The Fringe of London: Being Some Ventures and Adventures in Topography. London: Cecil Palmer, 1925.

Montefiore, Janet. Men and Women Writers of the 1930s: The Dangerous Flood of History. New York: Routledge, 1996. 
Orwell, George. The Clergyman's Daughter. New York: Harcourt Brace, 1936.

-. Coming Up for Air. 1939. New York: Harcourt Brace, 1950.

-. Keep the Aspidistra Flying. 1936. New York: Harcourt Brace, 1956.

Pathfinder. The Foot Path Way around London: Field, Path and Woodland Rambles, with Directions and Maps. London: The Homeland Assn., 1920.

Plain, Gill. Women's Fiction of the Second World War: Gender, Power and Resistance. New York: St. Martin's, 1996.

Priestley, J. B. English Journey. 1934. Chicago: University of Chicago Press, 1984.

Richards, J. M. The Castles on the Ground: The Anatomy of Suburbia. 1946. 2nd ed. London: J. Murray, 1973.

Saler, Michael T. The Avant-Garde in Interwar England: Medieval Modernism and the London Underground. New York: Oxford University Press, 1999.

Schneider, Karen. Loving Arms: British Women Writing the Second World War. Lexington, KY: University Press of Kentucky, 1997.

Severin, Laura. Stevie Smith's Resistant Antics. Madison, WI: University of Wisconsin Press, 1997.

Smith, Clive R. Golders Green As It Was. Greyhound Hill, UK: C. R. Smith, 1974.

Smith, Stevie. Collected Poems. 1976. Ed. James MacGibbon. New York: New Directions, 1983.

-. The Holiday. 1949. London: Virago, 1979.

- Me Again: The Uncollected Writings of Stevie Smith. Ed. Jack Barbera and William McBrien. New York: Farrar, Straus \& Giroux, 1981.

-. Novel on Yellow Paper. 1936. New York: New Directions, 1994.

-. Over the Frontier. 1938. London: Virago, 1980.

Spalding, Frances. Stevie Smith: A Biography. New York: Norton, 1989.

Stevenson, John. "Myth and Reality: Britain in the 1930s." Crisis and Controversy: Essays in Honour of A. J. P. Taylor. Ed. Alan Sked and Chris Cook. London: Macmillan, 1976. 90-109.

Waugh, Evelyn. Vile Bodies. 1930. Boston: Little Brown, 1958. 